\title{
FACTORS ASSOCIATED WITH MALNUTRITION AMONG LACTATING MOTHERS IN MIDDLE SOUTH TIMOR, EAST NUSA TENGGARA
}

\author{
Wenselaus Eric Paun, Sabina Gero, Pius Weraman \\ Masters Program in Public Health, Universitas Nusa Cendana, Kupang
}

\begin{abstract}
Background: Lactating mothers in the Nulle community health center (Puskesmas) have a habit of abstinence from certain foods, especially protein from meat and fish. They have smoked food culture, namely Se'I. Food abstinence in lactating mothers can affect the production of breast milk. This study aimed to investigate factors associated with malnutrition among lactating mothers in Middle South Timor, East Nusa Tenggara.

Subjects and Method: This was a cross-sectional study conducted in the area of Puskesmas Nulle, Middle South Timor, East Nusa Tenggara. A total of 102 lactating mothers was sampled at random for this study. The independent variables were Se'I culture and social capital (trust). The dependent variable was the nutritional status. Nutritional status was measured by weight and height. The other data were measured by questionnaire. The data were analyzed by multiple logistic regression.

Results: $34.3 \%$ of lactating mothers were malnourished. Se'I culture (OR $=2.5 ; 95 \%$ $\mathrm{CI}=0.50$ to 8.33; $\mathrm{p}=0.027)$ and low social capital $(\mathrm{OR}=1.53 ; 95 \% \mathrm{CI}=0.49$ to $4.79 ; \mathrm{p}=$ 0.002) were positively associated with malnutrition among lactating mothers.

Conclusion: Se'I culture and low social capital are positively associated with malnutrition among lactating mothers.
\end{abstract}

Keywords: Se'i culture, social capital, malnutrition, lactating mother

\section{Correspondence:}

Wenselaus Eric Paun. Masters Program in Public Health, Universitas Nusa Cendana, Kupang, East Nusa Tenggara. Email: ricoclaudey@gmail.com. Mobile: 081357287197.

The $6^{\text {th }}$ International Conference on Public Health Best Western Premier Hotel, Solo, Indonesia, October 23-24, 2019 | 146 